\title{
CONTROL OF SPURREY
}

\author{
By R. L. TAYLOR, Farm Chemicals Company, Port Mapua, Nelson
}

\section{$S U M M A R Y$}

Propham, chlorpropham, CDAA, and urea/carbonate were found very effective as pre-emergence treatments, MCPA and fenac partiali, effective, but PCP, dinoseb, CDEC, and EPTC quite ineffective. Simazine, atrazine, and monuron were effective.

As post-emergence treatments 2,3,6-TBA plus MCPA, MCPA, mecoprop, and 2,4-D were placed in this order of decreasing efficacy. MCPB and 2,4-DB were without any effect. The ammonium salt of dinoseb gave virtually complete control of small plants; sodium monochloroacetate (MCA) good control always better than the amine salt of dinoseb.

Prevention of seeding has been found very beneficial in limiting later germination. Spurrey (Spergula arvensis) in new pasture should be hard grazed before flowering.

\section{THE NEED TO CONTROL SPURREY}

Spurrey (Spergula arvensis) offers competition to crops at an early stage of their growth. Early competition has been shown to be very important in many crops including cereals. Early removal of spurrey is likely to increase yields even when the spurrey is doing no apparent harm.

The effect of spurrey on a crop depends a great deal on how vigorously both the crop and the weed are growing. Cereals have on some occasions been choked out by spurrey, but at other times have yielded heavily after outgrowing heavy infestations. Chou moellier suffers badly from spurrey in some districts, but not others.

Spurrey is well established in New Zealand in probably all districts suited to it, but other weeds notably fathen (Chenopodium album) and Amaranthus are not. In order to limit the seeding of such potentially more serious weeds inferior control of spurrey must of ten be accepted.

\section{PREVENTION OF SEEDING}

Various means of spread of spurrey seed are known but are no longer important in New Zealand. A heavy strike of spurrey can be assumed to arise in all cases from seed shed in a previous crop on the same ground. Spurrey is a prolific seeder yielding over 600 million seeds per acre in the heaviest infestations. Even when spurrey appears to be completely smothered beneath a heavy crop appreciable numbers of viable seed are formed.

Spurrey seed has a long life in suitable soil. Only 1 or 2 per cent of the seed is capable of germinating on ripening. Overwintering is necessary for good germination (1). Seed is most likely to strike the year after ripening.

Untreated strips 2 or $3 \mathrm{ft}$ wide were left in a crop of swedes heavily infested with spurrey when it was sprayed with MCA in April 1959. A heavy fall of rain in February 1960 brought up spurrey when the ground was under cultivation. The original strips were located and a count of spurrey plants made three weeks after the rain. Counts made at $10 \mathrm{ft}$ spacing by throwing a hoop of $1 \mathrm{sq}$. $\mathrm{ft}$. area from a short distance are given in Table 1 . The strips of heavy seeding were clearly defined after a grazing by sheep, two discings, and one harrowing, notwithstanding millions of dormant seeds in the soil from earlier heavy infestations.

A big reduction of spurrey coming up in later years has been observed when spurrey has been cut green in trial plots and removed, when portion of an infested crop has been disced in before seeding, or when part of a new pasture has been grazed before the spurrey has flowered. 
TABLE 1-NUMBER OF SPURREY PLANTS EMERGING THE FOLLOWING YEAR AFTER SPRAYING WITH MGA

\begin{tabular}{|c|c|c|c|c|c|c|}
\hline Treated & Untreated & Treated & & Treated & Untreated & Treated \\
\hline 7 & 43 & 8 & $\ldots$ & 0 & 14 & 1 \\
\hline 6 & 72 & 10 & $\ldots$ & 2 & 37 & 3 \\
\hline 6 & $12 \overline{7}$ & 13 & $\ldots$ & 2 & 44 & 0 \\
\hline 7 & 76 & 9 & $\ldots$ & 0 & 28 & 1 \\
\hline 10 & 84 & 2 & $\ldots$ & 4 & 21 & 6 \\
\hline 4 & 119 & 14 & $\ldots$ & 1 & 24 & 0 \\
\hline 7 & 91 & 19 & $\ldots$ & 0 & 32 & 2 \\
\hline 6 & 193 & 8 & $\ldots$ & 2 & 51 & 1 \\
\hline 18 & 74 & 16 & $\ldots$ & 1 & 50 & 1 \\
\hline 13 & 72 & 12 & $\ldots$ & 1 & 45 & 2 \\
\hline 17 & 29 & 2 & $\ldots$ & - & - & - \\
\hline Treated & Untreated & Treated & & Untreated & Treated & Untreated \\
\hline 8 & 31 & 1 & $\ldots$ & 29 & 12 & 58 \\
\hline 6 & 84 & 3 & $\ldots$ & 53 & 10 & 149 \\
\hline 11 & 22 & 0 & $\ldots$ & 86 & 7 & 110 \\
\hline- & - & - & $\ldots$ & 68 & 21 & 170 \\
\hline- & $\ldots$ & - & $\ldots$ & 108 & 18 & 125 \\
\hline - & - & - & $\ldots$ & 42 & 12 & 189 \\
\hline
\end{tabular}

SPURREY IN NEW PASTURE

Since new pasture is often the last crop of a series the most widespread occurrence of spurrey is naturally in new pasture. Such pastures should be hard grazed early to reduce the amount of spurrey seed formed and to prevent smothering of the white clover. Spurrey has no harmful effect on sheep (2) or cattle (3) even when eaten in large quantity. All but the most vigorous spurrey can usually be brought under control soon enough by grazing. Control is, however, sometimes difficult to achieve in heavy infestations, especially if grazing for some reason cannot be done when it is required. In these circumstances successful chemical treatment would clearly be advantageous. Spurrey does not survive in established grazed pasture, but isolated plants may occur, especially where subterranean caterpillar (Oxycanus spp.) is active.

\section{CULTIVATION}

For good germination of spurrey the top layer of soil must be maintained very wet for one or two days. This requirement is met either by a heavy fall of rain or by light rain over several days, during which the surface of the soil has no chance to dry out. Once the topsoil has dried it is unusual for much spurrey to germinate subsequently, even from heavy rain, provided the soil is undisturbed. Cultivation even to a shallow depth brings fresh seed to the surface and a second germination of spurrey is likely. For this reason successful spraying is often more effective in eliminating spurrey than a single cultivation.

Spurrey is easily killed by cultivation, especially in loose soil in hot weather. It may be harrowed out of peas or other crops after the spurrey is too big to spray, but in general cultivation is better done when the weeds are small and repeated if necessary.

Trouble from spurrey is less likely if planting is done when there is less risk of the soil becoming saturated with the first rain. Packing of the soil by rolling, etc., allows saturation to be achieved with less rain, and should be avoided in crops where it is not needed.

Ridging of crops is a big help in control of spurrey. Compaction and saturation of the soil are confined to the hollows where spurrey can be removed by scuffling. On top of the ridges spurrey plants grow more sparsely and initially more slowly unless rainfall is very regular. Ridging has the further merit of denying fertiliser to spurrey in the critical initial stage. Ridging and scuffling usually give adequate control of spurrey in brassica and fodder beet crops except in soil exceptionally favourable to spurrey or in seasons very wet after planting. 
Germination of spurrey is strongly favoured by a fine seedbed. Where spurrey is troublesome the soil should be worked no finer than required by the crop.

\section{FERTILISER}

In several countries spurrey is considered to occur more frequently on acid soils, but the extent to which it is checked by liming is still not clear. William Massey peas growing among vigorous spurrey in the wet spring and early summer of 1957 yielded 3 tons of green seed per acre where limed at 4 tons per acre, but less than $\frac{1}{2}$ ton per acre without lime. The soil was a poor sour clay. On this occasion it was apparent that as well as a beneficial action on the peas the lime had a depressing effect on the spurrey. ficial action on the peas the lime had a depressing effect on the spurrey. Otago on land which has been liberally limed, with $\mathrm{pH}$ values up to 6 . There is no evidence that lime should ever help spurrey, and in responsive crops especially peas, lucerne, and red clover heavy liming will help the crop to compete against spurrey.

Spurrey has been found to respond to phosphorus, sulphur, and nitrogen but not potassium, magnesium, boron or molybdenum in soils not very well supplied with these elements. Mostly there is likely to be some benefit from sowing superphosphate and nitrogenous fertiliser by drilling rather than broadcasting so as to make phosphorus, sulphur, and nitrogen more available to the crop and less available to the spurrey.

\section{PRE-EMERGENCE WEEDKILLERS}

Pre-emergence weedkillers were applied either by powered spray boom at 100 gallons per acre or by hand sprayer at 50 gallons per acre. No attempt was made to work the chemical into the soil. Good control of spurrey was obtained with effective chemicals and it is considered that working of the chemical into the soil is not required for spurrey, which germinates in the top inch of soil only. All chemicals were tried on a heavy clay soil of $\mathrm{pH}$ approximately 4.5 situated 4 miles due south of Motueka, and on a free draining silt of $\mathrm{pH} 4$ in the Riwaka Valley.

PCP and dinoseb have been used as post-planting pre-emergence weedkillers for some time and are still the only treatment recommended in beans and lupins. A reduction of spurrey up to 80 per cent has been claimed for these treatments.

PCP as an emulsifiable solution in oil and the triethanolamine salt of dinoseb were included in many trials at 3 to $4 \mathrm{lb}$ per acre. Control of spurrey was consistently poor. There was no weed present which PCP or dinoseb controlled better than chlorpropham, and the failure to control weed grasses was conspicuous. In very hot weather some very small effect was apparent, but in cooler weather more typical of that promoting spurrey the treated plots were indistinguishable from the untreated.

Propham and chlorpropham have been reported from many countries as very effective against spurrey. Chlorpropham is more expensive, but proportionately more effective. Propham is more volatile and may not have the required persistence, but in the present tests lasted for three weeks under the summer sun without rain without loss of efficacy. In hot weather spurrey seedlings were killed by chlorpropham shortly after germination, but in cooler weather took up to two months to die.

The least amount of chlorpropham for complete control of spurrey is about $\frac{1}{2} \mathrm{lb}$ per acre in light soils, about $1 \mathrm{lb}$ in average soils, and 2 to $3 \mathrm{lb}$ in the heaviest soils. This rate gives also good control of chickweed (Stellaria media) and Poa annua. Higher rates should of ten be used if the crop is tolerant, for other weeds are brought under control with heavier rates. Among the weeds present the following tolerated chlorpropham at $4 \mathrm{lb}$ per acre in heavy soil: Chenopodium pumilio, hawkweed (Crepis capillaris), catsear, (Hypochaeris radicata), sheep's sorrel (Rumex acetosella), and groundsel (Senecio vulgaris).

Low rates of chlorpropham sufficient for spurrey are tolerated by beet and brassica crops under favourable conditions and by many vegetable 
crops. Chlorpropham was used on carrots, silver beet, and rhubarb at $4 \mathrm{lb}$ per acre without injury, and on broad beans with some injury. Peas are depressed in yield by chlorpropham (4). In four trials blue lupins (Lupinus angustifolius) suffered no apparent damage from chlorpropham at $4 \mathrm{lb}$ per acre.

CDEC is recognised as safer to many crops than chlorpropham but less effective on weeds. Some slight check of spurrey seedlings was found on silt loam from $2 \mathrm{lb}$ per acre, but plots on heavy soil treated with $4 \mathrm{lb}$ per acre were indistinguishable from the untreated. Rather better control has been obtained by other workers.

EPTC was used in numerous trials. In very hot weather it gave some slight check to spurrey seedlings without reducing the number coming up, but in cooler weather was quite ineffective at $5 \mathrm{lb}$ per acre against spurrey, chickweed, fathen, or grasses. Some check was apparent at $10 \mathrm{lb}$ per acre, but was still inadequate. When combined with PCP or chlorpropham at various rates it did not improve their performance. Superlative swedes were not affected by $5 \mathrm{lb}$ per acre on heavy soil.

Urea/carbamate at $1.8 \mathrm{lb}$ per acre (6 pints) gave consistently good control of spurrey, almost as good as chlorpropham, but control of grasses was inferior.

CDAA has been reported as effective on grasses and spurrey (5). It is said to be most effective on heavy soils, unlike most pre-emergence weedkillers, and to be less dependent on rain. Good control of both spurrey and grasses was obtained, provided the rate was adequate. A reduction in rate was found to cause a bigger loss of performance than with chlorpropham. The minimum rate for good spurrey control was $2 \mathrm{lb}$ per acre in hot weather, but $6 \mathrm{lb}$ in cooler weather on both heavy clay and silt soils. In falling off in performance with cold weather CDAA contrasts with chlorpropham which was equally effective from January to May.

MCPA at $1 \frac{1}{2} \mathrm{lb}$ per acre was good, but inferior to propham, chlorpropham, urea/carbamate, or CDAA. MCPA is recommended for control of spurrey in newly sown ryegrass and cocksfoot in the high country in Kenya (6), but is not likely to find wide application in New Zealand, owing to its harm to germinating white clover.

Fenac at $3 \mathrm{lb}$ per acre suppressed the growth, but not the emergence of spurrey. Pre-emergence treatment was more effective than post-emergence, but was not good enough to count as successful.

Simazine and atrazine gave good control at $2 \mathrm{lb}$ per acre. Atrazine gave complete control of all weeds, yet did no damage to blue lupins.

Monuron, diuron, fenuron, and neburon may be used at low rates to control spurrey in suitably tolerant crops. The lowest rate of monuron for useful control of spurrey is about $6 \mathrm{oz}$ per acre in average soils, but $1 \mathrm{lb}$ per acre is needed for good control. Brassicas and many other crops will not tolerate even $6 \mathrm{oz}$ per acre, and many important weeds such as fathen, amaranthus, and fumitory (Fumaria officinalis) require rates much higher than spurrey.

PRE-EMERGENCE TREATMENT AFTER SPURREY IS UP

Spurrey is one of the quickest germinating weeds, and after a heavy rain is likely to be up some time before the crop, particularly if the crop is slow germinating. This may provide an opportunity to spray spurrey at an extremely susceptible stage before the crop is up, for spurrey, unlike many other weeds, usually comes up within a period of two days. Spraying should be done with the ammonium salt of dinoseb at $\frac{3}{4} \mathrm{lb}$ per acre or the emulsifiable solution of PCP at $1 \mathrm{lb}$ per acre. PCP is just as effective as dinoseb, but rather less poisonous and more acceptable for aerial spraying. The sodium salt of PCP is not sufficiently effective. MCA could be used in tolerant crops but will give inferior control.

In view of the difficulty of covering each weed thoroughly in spraying with the above chemicals, chlorpropham has been tried on spurrey as a post-emergence spray. Results were very encouraging. Chlorpropham may 
prove successful in practice, provided it is applied at the first opportunity after the spurrey is through. Even when no rain fell after spraying the chlorpropham the spurrey control was reasonably good.

HORMONE WEEDKILLERS

MCPB and 2,4-DB have no perceptible effect on spurrey even when applied at heavy rates to seedlings.

2,4-D is poor whether as sodium salt, amine salt, or ester. A small increase in performance of the butyl ester has been observed from the addition of mineral oils, especially damaging oils, but no variation in the formulation of 2,4-D can make it other than a poor material for spurrey.

A striking example of when not to use 2,4-D is provided in a trial done on a mixture of spurrey and subterranean clover (Trifolium subterraneum, Mt. Barker variety) both growing vigorously. Sixteen foot square plots were sprayed with the butyl ester of 2,4-D, MCPA, and MCA. The oil was varied in the 2,4-D, but the emulsifier was kept constant. Results are given in Table 2. It will be seen that the effect of 2,4-D was to increase spurrey in all plots. In the 2,4-D plots the second cut represented mainly ryegrass, which has come into these plots in place of the clover; in all other plots the second cut was largely subterranean clover.

TABLE 2-TOTAL GREEN WEIGHTS IN THOUSANDS OF POUNDS PER AGRE

\begin{tabular}{|c|c|c|c|}
\hline $\begin{array}{l}\text { First cut } \\
\text { Approx. } \\
\text { per cent } \\
\text { Spurrey }\end{array}$ & $\begin{array}{l}\text { ust } 1959 \\
\text { Yield }\end{array}$ & & $\begin{array}{c}\text { Second cut } \\
\text { November } \\
1959 \\
\text { Yield }\end{array}$ \\
\hline 98 & $\begin{array}{l}18 \\
20\end{array}$ & $\begin{array}{c}\ldots \\
\ldots \\
\ldots\end{array}$ & $\begin{array}{l}10 \\
14\end{array}$ \\
\hline 99 & $\begin{array}{l}18 \\
18\end{array}$ & $\ldots$ & $\begin{array}{r}11 \\
9\end{array}$ \\
\hline $\begin{array}{l}98 \\
95 \\
50 \\
60 \\
60\end{array}$ & $\begin{array}{r}20 \\
24 \\
9 \\
7 \\
25 \\
24 \\
23 \\
24 \\
24 \\
25 \\
25 \\
22 \\
24\end{array}$ & $\begin{array}{l}\ldots \\
\ldots \\
\ldots \\
\ldots \\
\ldots \\
\ldots \\
\ldots \\
\ldots \\
\ldots \\
\ldots \\
\ldots \\
\ldots \\
\ldots \\
\ldots \\
\ldots\end{array}$ & $\begin{array}{r}8 \\
9 \\
21 \\
29 \\
17 \\
15 \\
15 \\
12 \\
18 \\
16 \\
16 \\
24 \\
20\end{array}$ \\
\hline
\end{tabular}

2,4,5-T is not very effective, being comparable with 2,4-D.

Mecroprop is a little better than 2,4-D, but is inferior to MCPA. In this respect spurrey contrasts with the closely related chickweeds (Stellaria media; Cerastium spp.), catchfly (Silene spp.), and pearlwort (Sagina spp.), which are especially responsive to mecoprop.

MCPA is appreciably better than mecoprop and much better than 2,4-D (8), and may be used to give a useful check to spurrey in cereal crops. There is an advantage in spraying the weed small, but it is not so great as to require spraying before the 6-leaf stage of the cereal crop. It is probably best to wait for the 6-leaf stage and then apply at least $1 \mathrm{lb}$ acid equivalent per acre. A good deal of viable seed is likely to be formed even after $1 \frac{1}{2} \mathrm{lb}$ acid equivalent of MCPA per acre.

2,3,6-TBA: The effect of MCPA is increased by 2,3,6-TBA, which alone however has little effect. The combination twists the spurrey more than 
MCPA; the stems thicken where they twist most and do not grow out so straight as they do after recovery from MCPA, mecoprop, or 2,4-D. The strong synergism shown by $2,3,6-\mathrm{TBA}$ on MCPA is apparently not due to improved penetration because the effect is not diminished by spraying the 2,3,6-TBA and MCPA separately.

Half pound per acre of 2,3,6-TBA plus $\frac{1}{2} \mathrm{lb}$ per acre MCPA appeared little better than $1 \frac{1}{2} \mathrm{lb}$ MCPA alone, but in view of overseas evidence ( 7 ) the combination must at present be regarded as a more reliable treatment.

On rare occasions MCPA has given a complete kill of spurrey. An interesting result was a complete kill by both MCPA and mecoprop in February 1960. Drought was interrupted by 3 in. of rain on 1 February, after which the drought continued with bright sun every day for weeks Spurrey plants emerging as soon as 36 hours after the first fall of rain were sprayed a week later. The sprayed plants could not make enough root growth to keep up with the retreating soil moisture. Not a single plant survived in plots treated with MCPA or mecoprop out of about 4,000 in each plot, though there were six survivors in the adjoining ammonium salt of dinoseb plot and 82 in the MCA plot.

This result is exceptional and is unlikely unless plants are dying of drought. In general spurrey is most susceptible to hormone weedkillers when it is making rapid growth, and this may well be in cold weather.

MCPA plus MCA: MCPA is chemically compatible with MCA and a mixture suggests itself for treating spurrey in cereals in the presence of fathen or thistles. One pound acid equivalent of MCPA combined with $10 \mathrm{lb}$ MCA per acre outperformed $15 \mathrm{lb}$ per acre MCA alone in one trial on spurrey at a relatively advanced stage. This mixture merits further work. The safety of the cereal crop must be considered especially as some MCPA is known to contain wetting agents.

\section{CONTACT WEEDKILLERS}

DNOC is superior to dinoseb for many weeds, but is inferior for spurrey. It is more damaging to legumes, but easier on cereals. It is nevertheless being replaced in many countries by dinoseb and recommendations for the use of dinoseb on cereals are now available in many countries, including the U.S.A. (9). DNOC is holding its place in western Europe, where experimental evidence has been obtained justifying its continued use in cereal crops.

Dinoseb: Seedling spurrey is very susceptible to the ammonium salt of dinoseb, but becomes resistant when whorls begin to form along the firs branches. The change from fully susceptible to resistant is usually rapid and may be accomplished in a week. The resistant stage is reached at a time determined more by size than age. Fast growing spurrey may attain resistance to dinoseb as soon as three weeks after emergence.

Up to the resistant stage the ammonium salt of dinoseb gives virtually 100 per cent kill of spurrey, provided good coverage is obtained. There is little advantage in spraying in hot weather (8). Numerous plots were sprayed in varying weather with a hand sprayer at $50 \mathrm{lb}$ per square inch with $\frac{\mathbf{3}}{4} \mathrm{lb}$ in 50 gallons per acre. More than 99 per cent of spurrey plants have been killed whenever a hollow cone nozzle was used, provided the spurrey has not reached the resistant stage of growth. Poorer control commonly obtained with booms is due to spraying too late or to inadequate coverage. Low volumes of water put through fan nozzles at low pressure do not form enough drops adequately to cover such spindly plants as spurrey.

Rates up to 50 gallons per acre give better coverage of spurrey. Beyond 50 gallons per acre improved coverage is offset by run-off. Fortunately there is even greater run-off from peas, lucerne, or white clover, and for the same degree of crop damage it is possible to increase the rate of dinoseb a little and to atomise the spray finer. In this way better control of spurrey can be achieved with increasing volume up to at least 100 gallons per acre Such large volumes are considered seldom worth the cost and it is usual to strike a compromise at something below 50 gallons per acre. If fine atomisation is used the operator must be protected from spray drift. 
The triethanolamine salt of dinoseb was found not very effective on even seedling spurrey. Two pounds per acre of the amine salt was compared with $\frac{3}{4} \mathrm{lb}$ per acre of the ammonium salt on frequent occasions in a variety of weather and was always poorer. Indeed, there was never any doubt about fitting MCA in between the two in grading for performance. A much closer performance by these two formulations has often been reported. It is possible that the widespread use of fan nozzles and low volumes has obscured the real difference between the two formulations of dinoseb, because of the inability to get good results with either.

Owing to its poor performance the amine salt of dinoseb should not be used to control spurrey in peas or even in lucerne. Recommendations to allow the peas to grow $4 \mathrm{in}$. high before spraying with the ammonium salt of dinoseb cannot always be met without letting the spurrey get resistant. A liberal interpretation of the 4 in. requirement is necessary if the spurrey is thick.

MCA has been found effective in the Nelson district up to an appreciably larger size than DNBP. Its effect falls off gradually with age and a useful check has usually been obtained up to flowering. Such good control has not been achieved farther south, especially in Southland and Otago, but there is no explanation at present for these varying results.

MCA should be applied within the limits of 10 and $20 \mathrm{lb}$ per acre for spurrey. Rates below $10 \mathrm{lb}$ per acre are not effective enough on spurrey just through the ground. If $20 \mathrm{lb}$ per acre is ineffective, the spurrey has become resistant or coverage is not good enough, and an increase in rate will do little good. Good coverage is essential, but is hard to achieve on larger plants, especially in heavy infestations. MCA should be sprayed on crops as soon as they are tolerant.

Subterranean clover is checked by MCA, but has shown excellent recovery. White clover appears tolerant. Red clover and lucerne suffer too much damage from MCA and blue lupins are killed.

OTHER CHEMICALS

Useful control of spurrey, though inferior to that possible with preemergence weedkillers, is possible in certain crops with sodium nitrate at $250 \mathrm{lb}$ per acre, with white spirit at 40 gallons per acre, or with 5 per cent sulphuric acid.

\section{REFERENCES}

1. Prof. E. Aberg, Royal College of Agriculture, Uppsala, Sweden. Private communi-

2. H. E. Connor, Botany Division, D.S.I.R., Christchurch, and I. G. McIntosh, toxicologist, Wallaceville Animal Research station. Private communication.

3. Dept. of Agriculture, Govt. of the Netherlands. Private

4. L. G. Spencer; P. Gregory et al. Br. Weed

W. R. Aldous, Br. Wirch. J. Br. Grassland Soc. 1958

P. Gregory. Proc. 1st African Weed Cont. Conf.

8. T. Vidme. Report No. 18, Agric. Res. Board, Norway.

9. U.S. Dept. Ag. ARS 22-46, May 1958

\section{DISCUSSION}

Q.-Does GDAA give variable results, particularly on light land?

A.- It is most effective on heavier soils. On heavy clay soils heavier rates are needed; also heavier rates in winter than in summer.

Q.-Was chlorpropham compared on lupins with a hand-weeded control? Chlorpropham has reduced lupin yields in Departmental trials unless the seed was buried deeply.

A.- In a trial with 28 rows three weedy rows were hand weeded as per Dutch method. In this trial chlorpropham looks better than hand-weeded control.

Q.-Is there a satisfactory control of spurrey in lucerne?

A.-Dinoseb would be satisfactory. 
Q.-What were the rates of MCA used in trials?

A.-Fifteen pounds was the normal rate and $10 \mathrm{lb}$ the lowest rate, and the limit was $20 \mathrm{lb}$.

Q.- - Lambs are not keen on spurrey, but will tread it in. MCA gives variable control of spurrey in southern parts of South Island.

A.- Some sheep like spurrey, some do not; some may just tramp it in. Some authorities regard spurrey as good sheep feed. 